\title{
Reserrch Article: Weed dynamics of red rice + Sesbania aculeate intercropping system
}

\section{S. GANGADHARAN, C.R. CHINNAMUTHU, G. MARIAPPAN AND S.BOJA RAJ}

Article Chronicle : Received :

14.07.2017;

Accepted :

29.07.2017

KeY Words :

Red rice, Weed density, Drum seeding, Nutrient management, Intercropping

Author for correspondence :

\section{S. GANGADHARAN} Department of Agronomy, Adhiyamaan College of Agriculture and Research, Athimugam, KRISHNAGIRI (T.N.) INDIA Email: gangaagri360@ gmail.com

See end of the article for authors' affiliations
SUMMARY : Field experiments were conducted during Rabi 2015-2016 to study the effect different levels of fertilizers in green manure (Sesbania aculeate) inter cropping four drum seeded red rice varieties, viz., Chandikar, Nourguan, TKM 9 and TPS 1 on weed flora, total weed density and weed dry biomass. Among the four varieties, land race chanikar recorded the lowest grasses, sedges and broad leaf weed density. In-situ incorporation drum seeded daincha (Sesbania aculeate) at 30 DAS and application $75 \%$ RDF significantly reduced the total weed density and total weed dry biomass. Among the different combinations drum seeding variety Chandikar with Sesbania aculeate at $75 \%$ recommended dose of fertilizer (50:25:25 $\left.\mathrm{kg} \mathrm{NPK} \mathrm{ha}^{-1}\right)$ in two split application recorded the lowest total weeds density and lowest total weed dry biomass production.

How to cite this article : Gangadharan, S., Chinnamuthu, C.R., Mariappan, G. and Raj, S. Boja (2017). Weed dynamics of red rice + Sesbania aculeate intercropping system. Agric. Update, 12 (TECHSEAR-4): 10671072; DOI: 10.15740/HAS/AU/12.TECHSEAR (4)2017/1067-1072. 